\title{
Antagonism and Cooperation in Four Countries: Economic Policies and Performance
}

\author{
Fritz W. Scharpf
}

\section{Economic Performance: The End of Convergence}

The overall theme of this conference - "Industrial Societies After the Stagnation of the 1970 s" - may yet prove to have been prematurely optimistic. But while our difficulties may not yet be over, there is, indeed, general agreement with the proposition that we have been in a period of relative economic stagnation since the early 1970 s - at least when compared with the quarter of a century that went before. On the average, industrial societies suffered from lower economic growth, higher rates of inflation, and a return to levels of mass unemployment unheard of since the Great Depression of the 1930s. And even now, after a dozen years of crisis management, we have - at best - been able to solve the inflation problem while mass unemployment persists at the level of more than 30 millions in the OECD countries.

There is also agreement - or at least there should be - over the second proposition that differences between countries have increased significantly after the early 1970 s. While the indicators of economic performance of most industrial societies had become reasonably similar after the period of post-war reconstruction, they began to diverge once more in the 1970s. Some countries - like Japan, Norway or Austria - seemed almost unaffected by the general malaise and did remarkably well overall. Others - like Sweden, Italy, and the United States - seemed to pursue employment gains at the expense of price stability, and still others - like Switzerland and West Germany - seemed willing to accept considerable employment losses in their successful battle against inflation. The data are all there in the papers presented by Bolle/Greffe and by Manfred Schmidt in this volume.

But while there is agreement that something has generally changed for the worse in the early 1970 s, and that industrial societies have responded rather differently to the worsening economic environment, there is almost complete disagreement over what it is that has changed and over the factors which might explain the differences in the economic performance 
of different countries. The second issue is very well covered in Manfred Schmidt's excellent contribution to this conference. I fully agree with his incisive criticism of the literature - and I almost agree with the explanation that he himself proposes.

Schmidt suggests, essentially, that the successful management of the economic difficulties of the 1970s depended critically upon the institutional capability of some countries to rely upon "a high degree of concerted policy formation and high levels of stable consensus between capital and labour" - and he associates this capability with the presence of one or the other of two political conditions: either "labour commanded a dominant or hegemonic position" or "pronounced non-socialist, conservative-reformist tendencies have been in power". Countries were less successful, it would follow, when political forces were more nearly balanced or deadlocked - so that no single "camp" could coordinate all efforts from a position of accepted hegemonic leadership or, at least, with an effective preponderance of power.

In the context of the existing literature this is a highly sophisticated explanation, and it goes about as far as quantitative comparisons in political science could go. If I nevertheless suggest that it may not go far enough, it is because of the self-conscious limitation of its scope to the concerns of the professional political scientist. Yes indeed, institutional capabilities and the balance of political power are among the most important determinants of the responses of various countries to the economic crises of the 1970s and 1980s. But institutional capabilities are not general-purpose instruments, and neither are political power constellations. Both have their specific selectivity, permitting them to respond to some types of problem situations more effectively than to others. Thus, in order to adequately explain success or failure, we need to assess the "goodness of fit" between political and institutional capabilities on the one hand, and the specific requirements of the economic crises of the last decade on the other hand. Unless we are able to do so, our quantitative correlations may well be spurious, or at least unstable over time when the underlying economic problem changes its nature - which happened in $1979 / 80$ (with the consequence that, in the 1980s, Austria was less successful and the United States were more successful than Schmidt's hypothesis would have predicted) and which may well be happening again right now. 


\section{Short-Term Vs. Structuralist Explanations}

That means, of course, that even in political science studies we ultimately cannot dodge the questions of what was and is the nature of the underlying economic problems and which strategies of national economic policy might or might not succeed under such conditions. Yet a mere glance at the state of this discussion among economists might be enough to drive us back to our own concerns. Shortly after the beginning of the crisis, it is true, mainstream economists were at least able to agree on a common diagnosis which is neatly summarised in the following quote from the McCracken-Report to the OECD in 1977 (14):

... our reading of recent history is that the most important feature was an unusual bunching of unfortunate disturbances unlikely to be repeated on the same scale, the impact of which was compounded by some avoidable errors in economic policy.

The "unfortunate disturbances" were, of course, the first oil price shock of 1973/74 and the more general food and raw materials shortages preceding and accompanying it. Equally unsurprising, the "avoidable errors in economic policy" in the eyes of the McCracken group were, in the first place, the inflationary financing of the Vietnam war by the United States, and then the lack of determination of major countries in their fight against inflation in the early 1970 s and, perhaps, the continuation of deflationary policies in some countries after the onset of the crisis. There was nothing, in short, that more intelligent and energetic macroeconomic management could not have avoided, or could not now correct. But these were happy days, theoretically speaking.

In the meantime the technocratic optimism of such ad hoc explanations has long been replaced either by the deep gloom of secular theories of stagnation or by the flagellantism of structuralist explanations of the crisis. The first tend to emphasise the utterly exceptional conditions of the post-war decades, and to interpret the difficulties of the 1970s and $1980 \mathrm{~s}$ not as a temporary crisis but, rather, as the long-delayed return to capitalist "normalcy" (Borchardt 1982, Lutz 1984), or they tend to revive Kondratieff-Schumpeterian speculations about the "long waves of capitalist development" which also would support expectations of an inexorable economic decline during the present decades (Eklund 1980). In either case there is very little that economic policy could do to avoid or alleviate the crisis.

Structuralist explanations, on the other hand, tend to emphasise either the "institutional sclerosis" of over-organised and over-regulated economies (Olson 1982), or to lament the disastrous consequences of union power and of the tax burden of the welfare state for the vitality of 
capitalist economies. Even Michael Bolle and Xavier Greffe seem to subscribe to this type of structuralist analysis when they interpret present difficulties as a "crisis of regulation" in which "investment quotas have sagged in Western European countries" because of the "profit squeeze" exerted by improvements of the real wage position and because of "rigidities of the labour market". Again, there is not much that conventional economic policy could do about the problem - except to reduce the tax burden of the welfare state, to deregulate the economy and the labour market, and to weaken the organisational strength and the conflict potential of unions through appropriate industrial-relations legislation - all in the hope of revitalising the "animal spirits" of investors and entrepreneurs. This is, of course, the strategy adopted in Britain and other European countries after 1979, and in Germany after 1982. While it may have helped to increase profits and to reduce the rate of inflation, it certainly has not yet demonstrated its effectiveness in combatting mass unemployment.

So where does that leave us in our effort to understand the nature of the economic problems of the past decade - and to identify those economicpolicy measures which could have explained the relative success of some countries? It seems to me that we would do well to return to the more short-term and ad hoc analysis of the McCracken Report. Such a world view does not ignore the possibility of longer-run structural problems indeed it will be shown that the mismanagement of short-term problems is likely to create all the long-term problems that the structuralists have focused upon. I further assume, without being able to demonstrate it in this paper, that the necessary longer-term structural change would have been more easily accomplished if the short-term (random or cyclical) "disturbances", of which the McCracken report was speaking, had been managed better. In short, I suggest that the failures of short- and mediumterm macroeconomic management ought to be taken more seriously than is currently fashionable in the search for explanations of our economic woes.

The early 1970 s were undoubtedly a period in which several things had gone wrong at the same time in terms of short-term macroeconomic management. There was, first, a good deal of demand-pull inflation, much of it generated by an oversupply of US dollars which central banks were obliged to buy at fixed exchange rates. And just when the transition to a regime of floating exchange rates in 1973 provided national governments with a new freedom to pursue their own stablisation goals, inflation received an enormous cost push from exogenous increases of food, raw materials and, above all, oil prices. Thus, the battle against inflation became even more urgent.

At the same time, however, the three- or four-fold increase of oil prices 
within a few months meant that purchasing power was being transferred to the OPEC countries on a massive scale. Even if they had been able to immediately "recycle" their additional income into additional demand for consumer and capital goods, the result would have been major problems of structural adjustment among the industrialised countries. As it turned out, however, it took about two or three years before the OPEC countries were able to fully absorb their new wealth. In the meantime the accumulation of OPEC surpluses in the amount of 55 billion US dollars in 1974 created a demand gap of similar proportions in the industrialised world. If nothing was done about it, the predictable result was an increase in demand-deficient unemployment.

Economic-policy makers, in $1974 / 75$, were thus confronted with the double-barrelled threat of cost-push inflation and demand-gap unemployment just at the time when they were beginning to succeed in their battle against the previous problem of demand-pull inflation. If they found themselves limited to macroeconomic demand management with the conventional armatorium of expansionary or restrictive fiscal and monetary policy, they were in serious trouble. Should they choose to fight unemployment with expansionary measures, they would allow firms to pass on cost increases and they might rekindle demand-pull inflation as well. But if they chose to fight inflation instead, restricting aggregate demand could not directly influence the exogenous cost increases themselves. The best that could be achieved was either a profit squeeze (if firms were prevented from recovering their higher costs through higher prices) or a reduction of output (if firms were able to pursue a mark-uppricing policy in the face of inadequate aggregate demand). In either case the consequence would be increasing unemployment and a reduction of investment which would reduce future employment opportunities.

From this dilemma there was one - and only one - escape in the 1970s: if a country was able to rely upon effective incomes policies in addition to the conventional instruments of expansionary and restrictive fiscal and monetary policy, its economic policy would gain additional degrees of freedom which might be used to fight inflation and unemployment simultaneously. The crucial element was wage restraint. If increases in unit labour costs could be kept below the rate of inflation, the cost-push pressure on prices could be significantly reduced, leaving the government free to defend full employment by stabilising aggregate demand through expansionary fiscal and monetary policy measures.

This, then, was the "Keynesian" economic hypothesis underlying the imputed success of labour-dominated consensual strategies during the crisis of the 1970s: if there was an implicit or explicit understanding between the government and the labour unions under which the unions would exercise wage restraint while the government was reflating the 
economy, the unions would assume the responsibility for combatting cost-push inflation while the government could pursue full employment without having to pay the price of accelerating inflation. Yet, if the economics of success were so essentially simple - why was it that so few countries were actually able to pursue the concerted strategies necessary to their realisation? The answer lies, I suggest, in the institutional difficulties of the potentially successful economic strategy.

\section{The Difficulties of a Keynesian Solution}

In order to appreciate the difficulties of the Keynesian solution, we need to look more closely at the constellation of interests which is involved. Let us begin with the point of view of a "labour-dominated government." It must be concerned with both problems, inflation and unemployment. But - given its dependence upon the labour vote and upon the political support of organised labour, it also must have a clear political priority for avoiding open unemployment at almost any cost. From the perspective of such a government, then, the strategic "concertation" of wage restraint with demand reflation (the upper right cell of Figure 1) is clearly the preferred solution.

When viewed from the union perspective, however, the interest constellation is much more ambiguous. For unions, unemployment - or the threat of rising unemployment - is even more of a problem than it is for labour-dominated governments, but inflation as such is less of a union concern. Instead, unions have a strong interest in increasing the real income of their members, and inflation matters only to the extent that nominal wage increases are wiped out by it. Thus, if they could be sure that the government will in fact maintain full employment, they would always be tempted to shift from wage restraint to an expansionary wage

\begin{tabular}{|c|c|c|c|c|}
\hline & & & \multicolumn{2}{|c|}{ union wage policy } \\
\hline & & & expansionary & restrictive \\
\hline \multirow{2}{*}{ 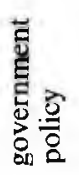 } & expansionary & $\begin{array}{l}\text { unemployment } \\
\text { inflation }\end{array}$ & $\begin{array}{l}\text { low } \\
\text { very high }\end{array}$ & $\begin{array}{l}\text { low } \\
\text { low }\end{array}$ \\
\hline & restrictive & $\begin{array}{l}\text { unemployment } \\
\text { inflation }\end{array}$ & $\begin{array}{l}\text { very high } \\
\text { low }\end{array}$ & $\begin{array}{l}\text { high } \\
\text { very low }\end{array}$ \\
\hline
\end{tabular}

Figure 1 Payoff Matrix of a Labour-Dominated Government 
policy. This temptation is strongest for very small unions or in companylevel bargaining, where inflation appears as a "collective evil" that could not be much reduced by one's own wage restraint, while one's own real incomes would suffer very much from the inflation generated by wage increases elsewhere. Thus it would be entirely rational for all small unions to push for the highest nominal wage increases which they could obtain.

Very large unions on the other hand (or the union movement as a whole) would at least have to consider the impact of high nominal wage increases upon inflation and, hence, upon real wages - and they might also take into account the difficulties which aggressive wage policies might entail for the continuing political viability of government full-employment policies (which for small unions is also a collective good that would not be much influenced by their own strategies).

\begin{tabular}{|c|c|c|c|c|}
\hline & & & \multicolumn{2}{|c|}{ union wage policy } \\
\hline & & & expansionary & restrictive \\
\hline \multirow{2}{*}{ 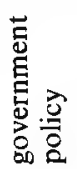 } & expansionary & $\begin{array}{l}\text { unemployment } \\
\text { real wages }\end{array}$ & $\begin{array}{l}\text { low } \\
\text { high }\end{array}$ & $\begin{array}{l}\text { low } \\
\text { low }\end{array}$ \\
\hline & restrictive & $\begin{array}{l}\text { unemployment } \\
\text { real wages }\end{array}$ & $\begin{array}{l}\text { very high } \\
\text { high }\end{array}$ & $\begin{array}{l}\text { high } \\
\text { low }\end{array}$ \\
\hline
\end{tabular}

Figure 2 Payoff Matrix of a Small Labour Union

The reason for this concern arises from the fact that even labourdominated governments must be politically sensitive to the demand for price stability. Thus, if the unions would not offer sufficient protection against inflation, the government might eventually have to shift to a more restrictive policy stance, or it might be displaced by a conservative government that was willing to realise aggregate demand in order to fight inflation. In either case the payoff of union wage strategies would change radically. As a consequence, unemployment would rise - and the unions would be defenseless against it. Once the money supply was effectively reduced, raising real wages could not increase effective demand - but it would surely create a profit squeeze that would push up "classical" unemployment. Thus, in order to minimise employment losses, the unions would now be pushed back, willy-nilly, towards the wage moderation from which full-employment policies had tempted them away.

Ironically, it is the small unions and company-level bargaining units that would have the greatest incentive to "cooperate" with a severely 
restrictive government policy. Unlike inflation, unemployment is not a "collective" but a "private evil" which is directly affected, to some degree by the wage costs of individual firms. Thus, the smaller the bargaining unit the greater would be the willingness of workers to save their own jobs through wage concessions - even if that kind of competition would push wages down for everybody.

It is obvious, therefore, that the ideal "Keynesian concertation" of government and union strategies does not represent a stable gametheoretical equilibrium. If the government is in effect "labour dominated" (meaning that it is politically committed to the full-employment priority), then the unions will be strongly tempted to pursue wage goals which are incompatible with their explicit or implicit responsibility for price stability. As a consequence, inflation may increase to politically intolerable levels - meaning that even a labour-dominated government may have to shift its priorities, or that it will be replaced by a conservative government committed to the fight against inflation as its topmost political priority.

When that happens, however, the unions have no choice but to restrain their wage demands while unemployment remains high. And unemployment is likely to remain high: if restrictive policies are pursued for any length of time, investment will have suffered, and the number of available working places will have been reduced below the level needed for full employment. Once that has happened, unemployment will have become "structural" - meaning that demand reflation could not eliminate it without inflationary overheating. Thus, the intersection of restrictive demand management and wage restraint may in fact represent a gametheoretical equilibrium - or a trap: government could not reflate the economy back into full employment even if it wanted to do so, and the unions would be forced by high levels of unemployment to maintain their general wage restraint.

Objectively speaking, the union movement as a whole would surely have every reason to avoid this least-favoured scenario. But in order to do so, it would have to solve two equally difficult strategic problems: it would need to forego certain short-term wage gains in anticipation of uncertain medium- or longer-term dangers, and it would need to discipline the rational egotism of its subunits in the interest of solidaristic strategies. The enormous difficulties of both tasks become obvious when one begins to examine the concrete historical experiences of four countries, Austria, Britain, Sweden, and the Federal Republic of Germany - all of which were led by "labour-dominated governments" at the beginning of the economic crisis. 


\section{Austria, Britain, Sweden, West Germany: Four Cases in Point}

Of the four countries only one, Austria, was in fact able to consistently pursue the concerted strategies discussed above at least until the end of the 1970s. As in most other countries, the first response of government fiscal policy to the crisis was expansionary - with a significant increase of the public deficit. As wage settlements were also undesirably high in 1974/75, the rate of inflation reached $10 \%$ in 1974 . Nevertheless, the government continued on its expansionary course, relying upon a combination of hard currency policy and union assurances of future wage restraint to deal with the problem of inflation. And, indeed, unit labor costs were reduced after 1975 , and inflation came down to around $4 \%$ by 1978 - even though registered unemployment never increased above the full-employment level of $2 \%$ until the end of the decade.

If the Austrian experience demonstrates the economic potential of Keynesian concertation strategies during the 1970s, the rise and fall of the "Social Contract" in Great Britain illustrates their institutional difficulties. In principle, the early responses to the crisis were similar in both countries - except that British wage settlements were much more exorbitant in 1974 and 1975 , so that the rate of inflation reached $24 \%$ by 1975. But after they realised the difficulties which this implied for the survival of the Labour government, the Trades Union Congress and individual unions agreed to a policy of wage restraint in order to curtail runaway inflation - and to allow the Labour government to continue its moderately expansionary anti-unemployment policy. And like in Austria, the policy was successful. By 1978 inflation had been dramatically reduced from $24 \%$ to $8.3 \%$ while employment continued to increase and unemployment, though higher than in Austria and Sweden, remained quite low.

But here the similarity ends: the Austrians with their highly concentrated structure of 16 industrial unions and with their highly centralised patterns of wage bargaining were able to implement wage restraint in an entirely business-as-usual fashion. Union leaders and employers associations were of one mind about the need for a determined but gradual reduction of wage pressures, and they simply planned their annual settlements accordingly. By contrast, Britain with her highly fragmented union structure of over 100 separate unions, many of them quite small and often competing with each other, and with decentralised patterns of shopfloor bargaining, had no chance whatever of treating wage restraint in the manner of ordinary business. Instead, the Social Contract could only succeed if the greatest possible publicity was employed to generate a maximum of moral, ideological, and political pressure upon individual 
unions and their shop stewards. The appeal was to "give a year for Britain," and the reference was to the "spirit of Dunkirk." Furthermore, in order to emphasise the solidaristic morality of the Social Contract (and also to discourage evasions through a simple and highly visible rule), the agreement was for a fixed-sum wage increase of 6 pounds per week for everybody during the first year, and for an even lower flat-rate settlement during the second year.

In the light of later events, it needs to be emphasised that the Social Contract was a dramatic success in its own terms, observed almost without exception during its first two years - and reducing the increase of unit labour costs from $29.4 \%$ in 1975 to $9.4 \%$ in 1976 . But moral fervor could not substitute indefinitely for the institutional weaknesses of an extremely fragmented union organisation, and flat-rate wage settlements were beginning to seriously distort a highly differentiated wage structure as well. In short: when the Callaghan government asked for a fourth year of the Social Contract in the Summer of 1978, union leaders were no longer able to offer their support - and a series of wildcat strikes escalated into official strikes of ever-increasing scope and bitterness, until the country came virtually to a standstill in the "winter of discontent" of 1978-79. The rest is modern history: Margaret Thatcher's resounding election victory in May of 1979 marked the end of any concerted government-union strategies in Britain, and as British unions learned the hard way to accept the non-negotiable discipline of monetarist demand management, British rates of inflation were coming down slowly while unemployment moved up much faster and has steadfastly remained above the 3-million level ever since.

The Swedish experience illustrates yet another variation of the same story. Again, the government's first response to the crisis was expansionary, and again wage settlements in 1974-75 were pushing up the rate of inflation. But when an agreement on wage restraint might have had a chance in 1976, the Social Democratic government lost the election (for reasons having less to do with economic management than with the dispute over nuclear energy). The bourgeois coalition, which came into power after 44 years of Social Democratic rule, had only one priority on which they could agree: they would continue to prevent open unemployment at almost any cost. And so they did. Being not close enough to the unions to negotiate any kind of concerted strategy, they combined repeated devaluations with the all-out subsidisation of employment in crisis-ridden industries - and with a continuation of Social Democratic policies increasing public sector employment and the employmentsubstituting measures of active labour market policy.

As a result, open unemployment in Sweden remained as low as it was in Austria, and the number of persons employed increased more than in any 
other European country. This is a remarkable achievement by any standards - even if one acknowledges that most of the additional employment was in part-time jobs for women in the local public and social services. The price which the bourgeois coalition governments were willing to pay was an escalation of public deficits - with interest payments of the national government exceeding one fifth of total expenditures in the early 1980 s.

But what about the unions? Surely not much love was lost between them and the bourgeois governments. Yet, on the other hand, Swedish union leaders in the 1950s and 1960s had developed a statesman-like sense of responsibility for the welfare of the national economy, and they were unlikely to abandon this self image merely because they did not agree politically with the government of the day. Apparently, something more serious must have happened to explain the inflationary push of Swedish wages in the late 1970 s and early 1980 s. Again, the best explanation that I have is institutional. Sweden is usually listed together with Austria as having the most concentrated and the most centralised union organisation. But, strictly speaking, that description holds only for blue-collar industrial unions united in the powerful "LO" which, until recently, was indeed able to conduct central wage negotiations across all sectors of industry. White-collar unions, on the other hand, had always been organised according to different principles, cutting across the jurisdictional demarkations of $\mathrm{LO}$ industrial unions.

For a long time these organisational anomalies had not mattered much as white-collar unions had been willing to accept the hegemonic leadership of LO in their own wage settlements. But with the increase of white-collar employment and with the increasing organisational strength of white-collar unions, that pattern changed. Aquiescence gave way to competition, and in some years the white-collar unions even usurped the wage leadership which LO unions had always claimed as their birthright. No wonder, therefore, that inter-union competition (and the effect of ubiquitous compensation clauses in wage settlements) prevented a return to the Swedish tradition of macroeconomically "reasonable" wage settlements during the time of the bourgeois coalition governments. Instead, Swedish inflation rates remained above average, and the profitability and international competitiveness of Swedish industry never recovered - despite a seemingly endless succession of devaluations of the Swedish krona.

Thus, when the Social Democrats returned to power in the Fall of 1982, unemployment was still very low, but the rest of the Swedish economy and, above all, the public budget were in a rather bad shape. Confronted with the urgent need to consolidate the budget, the new government virtually ended the expansion of public-sector employment as well as the 
subsidisation of employment in declining industries. Instead, it attempted to combine a once-for-all massive devaluation of the krona to stimulate exports and profits in the export industries with "social-contract"-like appeals for union wage restraint. By a lucky coincidence, this strategy profited from the export boom generated by the strong US dollar and American economic expansion after 1982. The closer political ties between unions and government and the moral pressure exerted by the government have also helped to dampen the effects of inter-union competition for the time being. But whether that will be enough to assure continuing success for the management of the Swedish economy remains to be seen.

The Federal Republic of Germany, finally, introduces an entirely new element into our account of the successes and failures of "labourdominated governments". The initial fiscal response of the federal government, to be sure, and of the Länder as well, was quite as expansionary as the fiscal policies which Austria had adopted. And increases in unit labour costs, while also inflationary in 1974, were far more moderate in 1975 and thereafter than those in Austria - or in any other OECD country, for that matter. Nevertheless, German economic policy did not achieve a successful concertation between government fiscal and monetary policy on the one hand, and union wage policy on the other hand, except for a brief period between 1977 and 1979.

But in contrast to Britain and Sweden, the problem in Germany could not be located on the union side. While their wage bargaining is not quite as centralised as it was in Sweden and still is in Austria, the organisational structure of the sixteen industrial unions in Germany shows the same degree of concentration as in Austria - and much less inter-union competition than was true in Sweden during the last decade. On the whole, those of the German unions which are capable of exercising wage leadership are also large enough (and economically sophisticated enough) to consider the macroeconomic consequences of their own wage settlements - which, of course, does not mean that these settlements should always please economic-policy makers in government or in the central bank. Thus, if concertation failed in Germany, the reason was not organisational problems of the unions - it was the very special role of the central bank.

In order to appreciate this point, we must first reexamine the notion of a "government fiscal and monetary policy" which we have used so far. This assumes an identity of the policy priorities and of the perceptions of policy makers in both fields - which may, or may not, exist in reality. If they had an entirely free choice, at least, one should expect that monetary policy makers would prefer policy priorities which are different from those of a "labour-dominated government". In general, it seems reasonable to 
assume that price stability will be their topmost priority and that unemployment, if it is considered a problem at all, will be a rather secondary concern of theirs. Thus, if a politically independent central bank were to consider its strategy choices vis-à-vis the choices of union wage policy, its payoff matrix might look as follows:

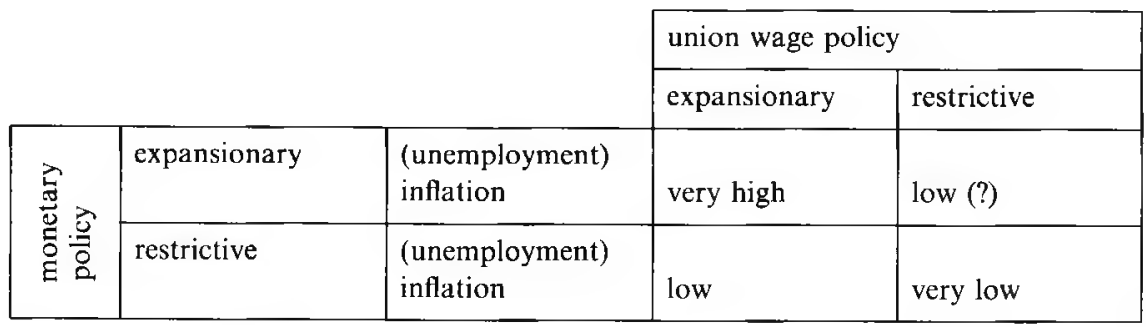

Figure 3 Payoff Matrix of an Independent Central Bank

Even if the unions might be trusted to exercise wage restraint when the government was committed to reflating the economy (which, from the bank's point of view must appear as a rather doubtful proposition), monetary policy makers would still have an unconditional preference for restrictive policies. Not only would that put them on the safe side in case the unions would not deliver on their promises, but it would improve the outlook for price stability even if they did. And like virtue, price stability is never firmly assured and always in need of greater commitment and effort. Even now, with the annual rate of inflation below $1 \%$, the Deutsche Bundesbank will not relax its monetary vigilance - and the 1970s had never provided it with that degree of comfort.

The point would not be worth belabouring if monetary restraint were not such a terribly effective policy instrument with the capability of completely overwhelming the effects of fiscal expansion. By limiting the supply of money, it is able to constrain aggregate demand regardless of the size of the government deficit. At the same time, rising interest rates will increase the exchecker costs of public borrowing as well as the costs of private investment. They may also raise the exchange rate and discourage export demand. But that is not all.

The most important consequence of rising interest rates is an increase in the opportunity costs of investment capital. Household savings and the accumulated profits of enterprises need no longer seek productive investments in order to earn satisfactory rates of return. At high interest rates, government bonds and other financial assets may offer even more 
attractive opportunities to realise the potential "surplus value" of accumulated capital - and without the risk that is inevitably associated with productive investment. In order to compete, therefore, productive investments must offer higher rates of expected profits - which, of course, could only be achieved by reducing the competing claims of labour and of the state. As a result, rising interest rates will either reduce the comparative attractiveness of real investments - with the predictable result of an investment gap and a subsequent increase of "classical unemployment". Or they will require a compensatory redistribution in favour of the profits accruing to the capital factor - and at the expense of the shares going to labour and to government. In other words: when interest rates are increased, the "terms of trade" between capital, labour, and the state are changed in the favour of capital.

If that is so, the effective coordination between fiscal policy and monetary policy must be a second crucial precondition for the success of Keynesian full-employment strategies - certainly equal in importance with the "cooperative" capabilities of labour unions. Institutionally, that coordination was no problem at all in three of the four countries:

The Österreichische Nationalbank is a private-law corporation whose stocks are jointly owned by the government and by the "social partners", unions, and employers associations, which not only have seats on its governing board but also control appointments to the directorate. Thus, close personal and political ties among decision makers in all three areas may have been even more important for the uncomplicated concertation between fiscal, monetary, and wage policy than the formal controls exercised by government over the bank's policy decisions. The Bank of England, on the other hand, has no formal and few informal ties to the unions. But its formal position is that of a department of the Treasury completely subordinate to government directives. And while - under the watchful eyes of a highly articulate and influential financial press - its professional authority is usually respected, there is no question at all that monetary policy could ever conflict with the economic-policy priorities of the government. The same is true in Sweden, where the governors of the Riksbank are directly elected by the Parliament - assuring a political majority for the government of the day during each election period.

By contrast, the Deutsche Bundesbank (like the equally independent Federal Reserve in the United States) is a federal institution whose decision-making body is only partly appointed by the national government. In its monetary policy decisions, furthermore, it is entirely independent from any directives - the most the government could ask for is that a decision should be delayed for a few weeks to allow for further consultation. Thus, while the bank is by law requested to cooperate with the economic policy of the federal government, it is free to define the terms 
of such cooperation by its own lights. And since the fall of 1974, it has chosen to define cooperation in "monetarist" terms - meaning that the bank would announce its own targets for monetary expansion each year, inviting the government and the social partners to adjust their own policy choices accordingly. In a country whose political sensitivity to inflation problems is exceptionally high, and in a government coalition whose survival depended upon the continuing support of a "bourgeois" party, the Social Democrats in the federal government probably had good political reasons to avoid an open clash with the bank's anti-inflation policy, even if they should have disapproved of it.

The unfortunate result was that twice, in 1974 and in 1980-81, a relatively vigorous fiscal expansion was neutralised in its economic effectiveness by a sharply restrictive monetary policy. As a consequence, West Germany was among the two or three OECD countries with the lowest rates of inflation throughout the crisis period. But she was also among the countries which suffered the greatest losses of employment exceeded only by Switzerland after 1974 and by the United Kingdom after 1980. Thus, the fact that registered unemployment in West Germany remained below the OECD average in the 1974-79 period had little to do with a successful full-employment economic policy. It was mainly the result of policies reducing the supply of labour-mainly trough preventing further immigration and encouraging the emigration of foreign workers and through the effects of various forms of early retirement for older workers. Without these supply-side measures, registered unemployment would have risen much faster, crossing the two-million mark already between 1975 and 1977 - rather than in 1982.

\section{Concerted Action and its Institutional Preconditions}

To summarise: in the 1973-79 period, labour-dominated governments in highly-industrialised Western societies did indeed have a chance to maintain full employment and reasonable price stability. The economic precondition was a concerted strategy combining expansionary fiscal and monetary policy with union wage restraint. The institutional preconditions of success were a union structure capable of adopting and maintaining wage policies that would not fully exploit the opportunities for wage increases provided by full-employment conditions, and institutional arrangements within government that assured the subordination of monetary policy to the full-employment priorities of the government.

As it turned out, governments in all four countries did in fact attempt to achieve the economically optimal concertation of fiscal, monetary, and 
wage policy. But only in Austria were both of the institutional preconditions of success fulfilled to the same degree.

In the United Kingdom, and to a lesser degree in Sweden as well, the organisational structure of the union movement and the institutional arrangements for collective bargaining made wage restraint difficult to achieve. In Britain the attempt to use the ideological commitment of the "Social Contract" as a substitute for the inadequate institutional capabilities of the union movement was dramatically successful for a few short years - but then it failed even more dramatically in the "winter of discontent" of 1978/79. In Sweden the unions - because of wage competition within their own ranks and perhaps also because of a lack of political rapport with the bourgeois coalition governments - also contributed to wage-push inflation which the government was unable to control. But the government was willing and able to maintain extremely high levels of employment through subsidies to industry, through a very high volume of active-labour-market measures and, above all, through a rapid expansion of public-service employment. The price was an even more rapid increase of public deficits.

In the Federal Republic of Germany, finally, the institutional conditions on the union side did facilitate a consistent policy of wage restraint after 1974, and the federal government also pursued an expansionary fiscal policy at the beginning of the crisis. The German central bank, however, was institutionally capable of pursuing its own policy priorities regardless of the government's political commitment to full employment - and, economically, monetary restraint turned out to be more effective than fiscal expansion. The result was an extremely high degree of price stability and very high employment losses.

This, then, seems to be the combined economic and political explanation of the relative success or failure of the economic policies of four labour-dominated governments in the 1973-79 period. But why was it that the solution which worked so well for Austria in the 1970s seemed to run into ever increasing difficulties even in Austria in the 1980s, and seemed to fail completely when the French Socialists attempted to adopt it in 1981/82? And why is it that decidedly non-socialist regimes seemed to do remarkably well politically and reasonably well economically in the 1980s? The explanation which I propose is, again, economic and institutional at the same time - with the one qualification that in contrast to the 1970s there was now no plausible economic strategy which could have satisfied the policy priorities of labour-dominated governments.

Yet, what was it that changed so fundamentally in 1979? First, there was the second oil-price shock which, again, increased cost-push inflation and created a demand gap in the industrialised countries of over 100 billion US dollars in 1980. But, while the policy response of most 
industrialised countries to the first oil crisis had been Keynesian expansion, it now was monetarist restraint not only in the United Kingdom but, much more importantly, also in the United States. There, the Federal Reserve under its new chairman Paul Volcker had finally converted from a Keynesian to a monetarist perspective, and had decided even before the second oil crisis to squeeze out inflationary expectations through restricting the supply of money. The price push of the Iranian oil shock only helped to increase their determination. But as dollar interest rates increased, the debt burden of second- and third-world countries, which had rapidly built up during the recession of the 1970s, reached crisis proportions as well. Loans which could not be repaid had to be replaced by new and even more uncertain loans - whose interest rates did, of course, include a considerable risk premium over and above the rates in the United States.

As a consequence, the international level of interest rates increased to exorbitant heights after 1979. This, in turn, created an extremely hostile economic environment for all countries whose political priorities would have called for expansionary fiscal and monetary policies. If they insisted upon increasing their own money supply and lowering their internal interest rates, the international capital and money markets, whose responsiveness to differences in expected rates of return had become almost instantaneous during the 1970 s, would immediately respond with a withdrawal of funds from that country. The result would be a devaluation of the currency and an increase in the rate of inflation which, before long, would compel even governments with an unambigous priority for full-employment to switch to more restrictive policies. This, at any rate, is what happened when the newly elected Socialist government in France attempted to implement the full-employment strategy which had been successful in Austria during the 1970s.

While in the 1973-79 period, individual countries had still been free to pursue either expansionary ("Keynesian") or restrictive ("monetarist") policies, the rising dollar interest rates, combined with a steadily rising exchange rate of the US dollar, eliminated the choice of an expansionary monetary policy. Whether it fitted their political priorities or not, all governments were forced to "import" the monetarism of the United States. But, as the German example had already demonstrated in the 1970 s, that also increased the price, and reduced the effectiveness, of expansionary fiscal policy. And if government policy was restrictive, neither an expansionary nor a restrictive wage policy of the unions could hope to defend or recover full employment. In short: the worldwide switch to a monetarist monetary policy effectively eliminated the possibility of successful Keynesian solutions at the national level.

Of the four countries whose performance in the 1970s were discussed 
before, the United Kingdom had ceased to be "labour dominated" in 1979 and the Federal Republic in 1982 - or perhaps already in the Fall of 1980, when elections had increased the political weight of the Free Democrats in the Social-Liberal coalition. Under their new governments, both countries chose to embrace, rather than to fight, the monetarist discipline of international capital markets, and to accept rising unemployment as the inevitable cost of greater stability and of better opportunities for future economic growth.

Of the remaining two countries, Austria tried to stay on the course that had been successful in the 1970s. But with the effective loss of national control over the conduct of monetary policy, the burden which had to be carried by fiscal policy, by incomes policy, and by public-sector industries became much heavier, while unemployment nevertheless increased to levels that would have been politically unacceptable in the 1970s. Even though Austria, like everybody else, began to profit from the American economic recovery after 1982 , the need became ever more compelling to reduce the public deficit and to salvage publicly-owned firms that had been asked to operate more like employment agencies than like profitseeking enterprises. As a consequence, the "Austrian model" has lost much of its former appeal abroad.

The Swedish Social Democrats, after their return to power in the Fall of 1982 , did not have the option of staying on the previous course. The catastrophic deficits of the external balances and of the public budgets did require dramatically new policy departures. The new government chose to devaluate the krona by a rate which was larger than expected - and which provided protection against further capital flight. If it was possible to reestablish the conditions for wage restraint, the strategy might improve the profitability and international competitiveness of Swedish industry - but even under the best of circumstances, it would not quickly reduce the pressure on the labour market and, hence, it would not allow the government to reduce its financial commitment to active labour market policy without accepting increases in registered unemployment.

Finally, even if it would succeed in Sweden, the Swedish strategy unlike the Austrian model in the 1970s - could not be generalised without becoming economically self-defeating. Not all countries could at the same time devaluate their currencies to create an export boom. Thus it seems reasonable to conclude that neither Austria nor Sweden have been able to come up with a generally plausible strategy that could have assured fullemployment under the new conditions of the international economic environment of the 1980s. The reasons for that conclusion seem to follow directly from the analysis of the German difficulties in the 1970s:

If the international level of interest rates rises, the "terms of trade" between capital and all other claimants for shares of the gross national 
product are altered in favour of capital. As a consequence, there is an increase in the minimal level of profitablity which productive investments must achieve in order to compete with other opportunities for capital use. Devaluation combined with wage restraint in Sweden was one way of increasing the profitablity of investments in the export industries; Austrian-type subsidisation of investments, also combined with continuing wage restraint, was another. Any other form of increasing the profitability of productive investments over and above the minimum profitability defined by the level of international interest rates would also do. But in all cases, what was required was a purposeful redistribution of national income in favour of profits from productive investment. Or, to put the same conclusion in different words: during the 1970s, the interests of wage earners and capital owners (which, of course, might be the same persons) still converged in most countries in a joint interest in economic growth. After 1980, that coalition fell apart when capital was able to collect higher returns in the international financial markets than could be offered by reasonably profitable productive investments.

\section{The Dilemma of Labour-Dominated Governments}

Once that coalition of interests had fallen apart, labour-dominated governments also lost their comparative advantage over other political constellations. If the only chance of economic success did in fact depend upon the ability to increase the profitablity of investments sufficiently to catch up with the rising rates of return offered in the international capital markets, then any government that was politically bound to labour interests was at a disadvantage. The same was true, of course, of unions which were institutionally capable of solidaristic action. In either case, the greater degree of power would enable labour interests to resist attempts at forced redistribution in favour of capital interests. But the political battles which they might win were likely to be economically pyrrhic victories when the international environment provided more attractive alternative opportunities for capital. And no matter what degree of "encompassing" rationality might be achieved by a powerful labour movement and its political representatives: their capability for organised self-exploitation would always lag behind the degree of exploitation achievable in countries with weak or nonexistent labour unions and with "capitaldominated" governments. This, together with the massive expansionary impulses of huge public deficits, explains the phenomenal employment gains of the United States in the last few years.

One might, of course, reasonably ask the author of such dismal 
conclusions for suggestions of a more promising strategy which might allow labour-dominated governments to evade the unattractive choice between mass unemployment and voluntary submission to greater degrees of exploitation. Obviously, there are such suggestions - ranging from a single-minded pursuit of technological innovation in order to increase labour productivity (and, hence, the profitability of investments without the need to reduce wage incomes) to the uncoupling of employment opportunities from profits through an increase of publicly financed employment or through the solidaristic redistribution of working time (and incomes) between those who have jobs and the unemployed. But all of these solidaristic solutions could be described as "socialism within one class," because they would have to respect the greater distributive claims of capital owners. For that reason, they would all be less satisfactory, from a labour-dominated perspective, than the solutions which could have worked in the 1970s and before.

To end on a speculative note: could it be that the international economic situation was undergoing yet another fundamental change right now - and a change for the better, at that? The present fall of oil prices could indeed be interpreted as an "oil crisis in reverse" - with a reduction of cost-push inflation and an increase of effective demand within the industrialized world. At the same time, the falling exchange rate of the US dollar seems to create opportunities for lowering the interest rates of all other countries which had been foreclosed since 1980. Thus, at least for the time being, national Keynesianism might indeed work again.

And so it might - provided that the debt crisis of the Third World will remain in abeyance, and provided that OPEC will not be revived by the rapid fall of oil incomes. But even then, we should not expect that a return to the concerted strategies that were (or would have been) successful in the 1970 s would now suffice. At least in those countries which were not able to prevent mass unemployment from building up, we now have a large stock of structural unemployment which mere demand reflation, even if combined with wage restraint, could not eliminate. If governments tried to reflate the economy beyond the production potential of existing capacity, demand-pull inflation would reappear. And if governments and unions would try to stimulate additional productive investments to such a degree that the structural job deficit could be eliminated, they would again be compelled to attempt a massive redistribution in favour of capital interests. Thus, even if we were (temporarily - because the internationalisation of capital markets is likely to be irreversible) again in a situation in which national Keynesian strategies had a chance of success, we would still need to rely upon solidaristic strategies of publicly-financed employment, and of work sharing, in order to eliminate unemployment. 
The present essay, therefore, does not end on a happy note: the hope of the $1960 \mathrm{~s}$, that national governments might be able to achieve full employment and price stability and all other goals of economic policy at the same time, was disappointed by the worldwide economic crises beginning in the early 1970s. And while the economic environment then would have allowed Keynesian strategies to succeed, the institutional requirements of the necessary coordination between government fiscal and monetary policy, and union wage policy, were so demanding that only very few societies could have succeeded. In the 1980s, however, even that slender hope was destroyed by another change in the economic environment which transformed the terms of trade between capital, labour, and governments in favour of capital interests. In purely economic terms (i. e., without regard to issues of distribution), countries which offered the least institutional resistance against being exploited by capital interests were now at an advantage. Whether that situation is now changing again is still uncertain. But even if it is, the reduction of high levels of structural unemployment could not be accomplished without the institutional capability for solidaristic strategies which is so difficult to achieve.

\section{References}

Borchardt, K. (1982): Wachstum, Krisen, Handlungsspielräume der Wirtschaft, Göttingen.

McCracken, P. et al. (1977): Towards full employment and price stability, Paris: OECD.

Eklund, Klas (1980): Long waves in the development of capitalism, Kyklos, 33: $383-419$.

Lutz, B. (1984): Der kurze Traum immerwährender Prosperität: eine Neuinterpretation der industriell-kapitalistischen Entwicklung im Europa des 20. Jahrhunderts, Frankfurt/Main.

Olson, M. (1982): The rise and decline of nations: Economic growth, stagflation and social rigidities, New Haven. 